\title{
Stuart Hall
}

\section{Reflections, Memories, Appreciations}

\begin{tabular}{c}
\hline ANN CURTHOYS \\
UNIVERSITY OF SYDNEY \\
AND \\
JOHN DOCKER \\
UNIVERSITY OF SYDNEY \\
\hline
\end{tabular}

Stuart Hall was many things: public intellectual, academic leader, writer, editor, teacher, political activist, family man and friend. We write here of the two aspects we knew personally, writer and friend. Like so many of us engaged in the early formation of cultural and media studies, we both read and were seriously influenced by his work. John discussed Stuart Hall's work extensively in his $\mathrm{PhD}$ thesis on Australian literature of the 1890s in international contexts, and Stuart was one of his examiners. Ann read Stuart's work in the late 1970s, having just arrived to teach in the BA (Communication) degree at what was then the NSW Institute of Technology, ten years later to become University of Technology, Sydney (UTS).

Later, in the 1990s and 2000s, we came to know him personally through his wife, Catherine Hall, whom Ann met through their common interest in questions of ISSN 1837-8692

Cultural Studies Review 2016. ( 2016 Ann Curthoys and John Docker. This is an Open Access article distributed under the terms of the Creative Commons Attribution 4.0 Unported (CC BY 4.0) License (https://creativecommons.org/licenses/by/4.0/), allowing third parties to copy and redistribute the material in any medium or format and to remix, transform, and build upon the material for any purpose, even commercially, provided the original work is properly cited and states its license. 
race, empire and identity. Whenever we visited London, we would catch the Jubilee Line to West Hampstead, turn the corner into Ulysses Street, and be welcomed by Stuart and Catherine. During those visits, we became friends. While our intellectual engagements with his work, and our friendship, had emerged separately, on reflection they seem to have been closely entwined; for the ideas of both were influenced by the marriage. In John Akomfrah's documentary, The Stuart Hall Project, Stuart discusses the early years of his marriage to Catherine. It was during this period in his life, he says, in the second half of the 1960s in Birmingham, that he most experienced racism on a personal level. Being in a mixed race couple made both of them the object of racist insults and innuendo, and both were to write extensively about race in their later work.

One of Stuart's key ideas is that questions of race are foundational to and embedded within a whole range of other questions to do with class, empire, history, modernity, representation and popular culture. Race relations in Britain have a long history, which is still poorly understood. One of Stuart's statements most quoted in the obituaries has been this: "The very notion of Great Britain's "greatness" is bound up with empire. Euro-skepticism and Little Englander nationalism could hardly survive if people understood whose sugar flowed through English blood and rotted English teeth.' Stuart's comments here point to an issue of great importance: that despite the extensive legacies of empire there is a pervasive British amnesia about both its existence and its consequences for the present. This amnesia, as Stuart pointed out, influenced many of its intellectuals, including the more radical. We might consider here the case of E.P. Thompson. He was the son of an English missionary who served in India and who on his return to England wrote extensively about India and indeed even wrote a book titled The Making of the Indian Princes. Thompson, the son, wrote in 1963 one of the foundational texts of both modern historiography and of cultural studies, The Making of the English Working Class. Yet even Thompson did not understand the significance of empire for his exploration of the interplay between working people's experience, cultural values and a transforming politics during the rise of industrial capitalism in England.

For Stuart Hall, coming to England from Jamaica at the age of eighteen, and remaining there to become one of its most influential citizens, this kind of amnesia about empire and race was simply not possible. He emphasised that in the social 
crisis engulfing Britain from the 1960s to the 1980s, race did not generate the crisis, which had multiple causes and dimensions, but it punctuated and periodised it. He worried that those studying race relations were tending to abstract it from other issues, seeing it as something separate and external when it was not. Race, or more precisely the idea of race, was an integral part of Britain's imperial past and its rapidly changing present, and it helped shape English identity. In an essay published in 1997, he writes about the identity of Englishness. ${ }^{1}$ The English eye, he says, sees everything else but is not good at recognising that it is itself actually looking at something. It becomes coterminous with sight itself. Like other identities, Englishness seeks to be unitary, but in fact it can never be because of its role in the former British empire and because of the multiplicity of identities within Britain itself. In this discussion we see some classic aspects of Stuart Hall's thought: clarity, awareness of complexity and difference, identification of patterns and constellations and connections, and a sharp critical edge.

Later in his life, after his retirement from the Open University, Stuart's preoccupations turned very specifically to black diaspora art and artists in Britain, encouraging, supporting, interpreting and historicising. He wrote further theoretical reflections on the nature of diaspora and the legacies of empire, and occasionally reflected on his own background. His family origins, he says in The Stuart Hall Project, were 'part Scottish, part African, part Portuguese Jewish'; he could not explain his life by any one origin or fragment of ancestral and diasporic history. The Portuguese Jewish strand is especially intriguing, and allows us to ponder his work on identity a little further. It reprises the long and remarkable history of Sephardi Jews who were expelled from Spain in 1492, some of whom went into exile in Portugal and from there to liberal Holland in the seventeenth century, a history that most famously includes Spinoza. Significantly, it also reprises the figure of the Marrano, outwardly Christian, secretly Jewish, prefiguring modernity in terms of mixed, uncertain, contradictory identities. The Marrano was a connoisseur of ambiguity and ambivalence, of an ironic self-consciousness, playing with masks and a multiplicity of personae, heretical. Like Spinoza, like Georg Simmel's stranger, like Stuart Hall, the Marrano was inside and outside a society at the same time, disturbing and interrupting and energising it. In Simmel's terms, the Marrano was the wanderer who comes today and stays tomorrow. Stuart's intellectual sensibility 
was not Anglo-American empiricist but continental European, as in Walter Benjamin and Hannah Arendt. Stuart's intellectual sensibility was also akin to that of another exile, Edward Said, whom he often quotes.

Stuart's ideas were to influence many people, not least his wife Catherine, fourteen years younger and a distinguished feminist historian. After a series of books on British history, especially Family Fortunes, co-written with the wonderful late Leonore Davidoff, which stressed the role of gender in the making of nineteenth-century British culture, she turned to the issue of how the Empire made Britain, rather than the other way around. The result was her book Civilising Subjects: Metropole and Colony in the English Imagination 1830-1867, which moves back and forth between Jamaica and Britain in the mid nineteenth century to show in detail how the identity of being 'English' was formed in part through debates over what was happening in Jamaica. This has been an enormously influential book in British 'new imperial' and settler colonial history, including here in Australia, and it is clearly in conversation with Stuart's concerns with race, identity and empire.

When we visited Stuart and Catherine in West Hampstead over the years, only two among many people to do so, we had many lively conversations ('conversation' itself was, in fact, one of Stuart's favourite words in a theoretical sense). One was over the question of husband-wife collaboration. Why, we asked, had they never written anything together, though their interests were so close? The answer, Stuart said, was their considerable age gap-their careers peaked at different times. Another time, in 2012, Stuart talked about his progress in writing his memoirs. He had, he said, spent the last week writing angrily about his mother, and it was clear that his identity was in part bound up with rejecting her obsessive concern with race and status. He came to England to escape all that, but in fact, he said in another context, he never did; he simply found it in a different form.

Turning into Ulysses Street to visit Stuart and Catherine, John would often smile as he was reminded of another insider-outsider, James Joyce, the Irish outsider to Englishness who exiled himself in Europe yet created a remarkable novelistic language in English, just as Stuart created a beautiful conceptual language for the adventure of ideas we call theory. The name 'Ulysses Street' also can remind us of C.P. Cavafy's poem 'Ithaka', urging us as modern Odysseans to make our voyage a long one. It should be 'full of adventure, full of discovery', visiting 'many Egyptian 
cities to gather stores of knowledge from their scholars' or stopping at Phoenician trading stations to buy 'mother of pearl and coral, amber and ebony', that is, to make many and various journeys in our search for truth. In its closing stanza, 'Ithaka' refers to Odysseus' wisdom, 'so full of experience', and we can think here of the wonderful photos of Stuart as Odysseus, now old, his sculptured face etched with the wisdom of the ages.

Genevieve Lloyd, in her book on Spinoza, tells us that in the Ethics Spinoza proposes that the human mind cannot be absolutely destroyed with the body; there remains something of it that is eternal. So Spinoza, so Stuart Hall.

Ann Curthoys and John Docker are both honorary professors at the University of Sydney.

-NOTES

1 Stuart Hall, 'The Local and the Global: Globalization and Ethnicity', in Anne McClintock, Aarmir Mufti and Ella Shohat (eds), Dangerous Liaisons: Gender, Nation, and Postcolonial Perspectives, University of Minnesota Press, Minneapolis, 1997, p. 174.

\section{-BiBLIOGRAPHY}

Akomfrah, J., (dir), The Stuart Hall Project, U.K., Smoking Dog Films \& Lina Gopaul $<$ https://www.youtube.com/watch?v=IM9eZYLvzTc>.

Cavafy, C.P., 'Ithaka', trans. Keeley and Sherrard, The Official Website of the Cavafy Archive $<$ http://www.cavafy.com/poems/content.asp?cat=1\&id=74>.

Hall, C., Civilising Subjects: Metropole and Colony in the English Imagination 1830-1867, University of Chicago Press, Chicago, 2002.

Hall, S., 'The Local and the Global: Globalization and Ethnicity', in A. McClintock, A. Mufti and E. Shohat (eds), Dangerous Liaisons: Gender, Nation, and Postcolonial Perspectives, University of Minnesota Press, Minneapolis, 1997.

Lloyd, G., Routledge Philosophy Guidebook to Spinoza and the Ethics, Routledge, London, 1996. 